\title{
The Parabolic Effect of Managerial Ownership and the Impact Toward Firm's Performance
}

\author{
William Susanto and Kartika Nuringsih \\ Faculty of Economics \& Business, Universitas Tarumanagara \\ Email:william.115160198@stu.untar.ac.id, kartikan@fe.untar.ac.id
}

\begin{abstract}
The purpose of the study is to analyze the impact determinants and the parabolic effect of managerial ownership on a firm's performance. The model consists of managerial ownership, institutional ownership, family ownership, leverage, asset growth, dividend policy, business risk, and firm size. Purposive sampling is used on non-financial companies in the Indonesian Stock Exchange with a total observation of 539 firm-years. The panel least square is used to analyze the determinants of performance while Panel EGLS is used to analyze the parabolic effect. The study finds that managerial ownership, institutional ownership, dividend policy, and firm size have a positive and significant impact on the firm's performance. Contrarily, some variables e.g., family ownership, leverage, and asset growth have a negative significant impact on performance. Business risk is not able to prove a significant relationship with performance. Further, the study shows a parabolic effect of managerial ownership, therefore, it proves a model for reducing agency conflict on corporate financial decisions.
\end{abstract}

Keywords: Firm's Performance, Agency Conflict, Ownership Structure, Parabolic Effect of Managerial Ownership, Corporate Finance Decision.

\begin{abstract}
Abstrak: Tujuan penelitian ini untuk menganalisis dampak dari determinan dan pengaruh parabolik pada kepemilikan manajerial terhadap kinerja perusahaan. Model penelitian meliputi kepemilikan manajerial, kepemilikan institusional, kepemilikan keluarga, leverage, pertumbuhan aktiva, kebijakan dividen, risiko bisnis, dan ukuran perusahaan. Teknik pemilihan sampel menggunakan purposive sampling pada perusahaan non-finansial yang terdaftar di Bursa Efek Indonesia dengan total pengamatan 539 tahun-perusahaan. Panel least square digunakan untuk menganalisis determinan kinerja perusahaan sedangkan panel EGLS untuk menganalisis pengaruh parabolik kepemilikan manajerial terhadap kinerja perusahaan. Hasil riset menunjukkan kepemilikan manajerial, kepemilikan institusional, kebijakan dividen, dan ukuran perusahaan berpengaruh positif signifikan terhadap kinerja perusahaan. Sebaliknya, variabel seperti kepemilikan keluarga, leverage, dan pertumbuhan aktiva berpengaruh negatif signifikan terhadap kinerja. Risiko bisnis tidak membuktikan hubungan secara signifikan terhadap kinerja. Selanjutnya, penelitian menunjukkan efek parabolik kepemilikan manajerial terhadap kinerja perusahaan sehingga membuktikan suatu model untuk menekan konflik keagenan pada keputusan finansial perusahaan.
\end{abstract}

Kata Kunci: Kinerja Perusahaan, Konflik Keagenan, Struktur Kepemilikan, Pengaruh Parabolik Kepemilikan Manajerial, Keputusan Finansial Perusahaan. 


\section{INTRODUCTION}

According to the Statistical Bureu (2020), the economic growth of Indonesia has faced a downfall of $5.02 \%$ in 2019 . The downfall caused Indonesia to be considered unable to maintain its economic growth at the level of $5.3 \%$ as in 2018. Therefore, it becomes a target for Indonesia to increase its economic growth in 2020 which causes the firm's performance to play an important role in contributing to the purpose. Meanwhile, there are various factors to achieve optimal performance so this research puts a firm's performance as the main pillar to support the economy of Indonesia.

Generally, a firm's performance is analyzed by using the information in financial statements which means that corporate decisions on investing, financing, and dividendpaying will be in turn affect the firm's performance. For that reasons, this study analyzes the impact of the corporate decision toward firm's performance by involving the asset growth to represent the investment decision, debt financing to identify the effectivity of financial decision and its impact on firm's performance, and dividend policy to examine the welfare of stockholder as a result of dividend distribution and the impact of the dividend distribution on performance.

However, the conflict of interests between the manager (agent) and the owner (principal) affect to the quality of decisions making among managers. Therefore, it is relevant to the prior study of (Jensen and Meckling, 1976) which stated that managers often perform opportunistic behavior to benefit certain parties, or themselves, which resulting in agency conflict. Hence, this study is done with the purpose to describe the impact of ownership structure such as managerial ownership, institutional ownership, and family ownership and also to examine whether those ownership structures can be used as a mechanism to mitigate agency conflict. With the potential conflict of interest that may emerge, it is compulsory for the principal to monitor the manager's decisions but doing so increases agency costs that reduces firm's performance. Therefore, the firm's policy should balance the benefit and cost related to the agency relationship in order to increase the firm's performance.

In order to complete the model to reduce agency conflict, this study develops another determinant, such as business risk and the firm's size. Generally, the big corporates will have a better performance than smaller corporations. The statement is supported by prior studies e.g., (Ho and Mohd, 2019; Khan et al., 2019). However, there exist some large-scale companies that have been experiencing a decrease in price-to-book value during the period of 2014-2018, such as Gudang Garam and Indofood Sukses Makmur which is two of the biggest companies in Indonesia. The condition implies that the big corporate doesn't always have a better performance than the smaller ones. It is consistent with (Shan, 2017) and managerial utility maximization theory which states that when a firm grows, managers tend to make decisions to fulfill their interests and not to optimize profits, such as hiring more employees to help on his job but the additional employee doesn't really contribute to the firm's performance. Furthermore, uncertainty in the business environment causes the volatility of revenue and even worse causes business risk such as the firm's inability to meet its operational costs, and therefore an increase of business risk can reduce the firm's performance (Ko et al., 2017). Otherwise, the study of (Alshubiri, 2015) found which is when a firm experiences an increase of business risk, it will seek to overcome the risks by 
creating innovation and thus will result in an increase in the firm's performance from the new innovation that emerges during the crisis.

Based on the reasons, this study analyzes the determinants of the firm's performance of non-financial firms which are listed in the Indonesia Stock Exchange in 2012-2018. The total amount of non-financial firms is very high, so it is capable to represent corporate sectors in Indonesia. Meanwhile, the financial sector such as bank and insurance companies are not used as a subject in this study because it has some differences in terms of regulatory requirements and financial reporting standards (Allam, 2018). Besides, this study examines the parabolic effect of managerial ownership on performance, the possibility is very likely to occur as stated by (Morck, 1988) in the form of a convergence of interest hypothesis and entrenchment hypothesis. Based on the conditions, the research question as follows: (1) Do managerial ownership, institutional ownership, family ownership, leverage, asset growth, dividend policy, business risk, and firm's size have a positive impact on a firm's performance? (2) Does managerial ownership has a parabolic effect on a firm's performance? The results can be used as references about factors enhancing a firm's performance. It becomes a reference for investors in making decisions in the corporate area. Hence, investors can predict the level of risk-taking from investing activities. Academically, the result could be a referencing for students in terms of knowledge and literature review to conduct studies about a firm's performance, especially in mitigating agency conflict.

\section{THEORITICAL REVIEW}

Agency Theory. A study of (Jensen and Meckling, 1976) developed agency theory which states that there is a separation of ownership function and firm's management that occurs because the owner delegates tasks and authorities to the manager to manage the company. A lot of studies have been done to develop agency theory and its relevance to the firm's performance. The study of (Panda and Leepsa, 2017) concludes that the main problem of agency theory is a conflict of interest that encourages the manager to do opportunistic behavior. It causes the owner to monitor decisions taken by the manager with agency costs as consequences.

Agency costs induce a decrease of performance (Jabbary et al., 2013) so various studies have attempted to examine the role of ownership structure as the mechanism to mitigate conflict of interest. The ownership structure mechanism intends to decrease agency costs and increase the firm's performance as well. According to (Ali et al., 2018) stated that managerial ownership converges the interests of the owner and manager who has been the firm's owner so then the unification of interests can decrease agency costs. Further, (Kansil and Singh, 2018) stated that institutional ownership observes the manager's decisions better than the other ownership structure so it can decrease the manager's intention to do opportunistic behavior and will in time decrease agency costs. Relevant to (Shyu, 2011) that family ownership has more complete information about the firm than the other ownership structure so family ownership plays the role in decreasing asymmetric information between the owner and stakeholders which then will decrease agency costs.

Pecking Order Theory. The manager has a preference for financing sources in terms of making financing decisions. The theory defined the stages of the financial decisions through pecking order theory (POT) that was developed by (Myers and Majluf, 1984). POT explains that in general, the preference is internal financing (retained earnings) and external financing 
(debt and stock issuance). Manager will firstly use internal financing when the internal financing is not enough, then the manager will issue the debt instruments (e.g., short term debt, long term debt, and convertible bonds) before issuing the stock issuance such as preferred stock and common stock). Further, (Ahmed et al., 2018) stated POT is related to agency theory in terms of asymmetric information, which is when manager increases leverage, an investor tends to assume that the manager is avoiding stock issuance because the market price is under-valued (intrinsic value is higher than market price), thus it will decrease investor's trust and may decrease the stock price (Adair and Adaskou, 2015). It is consistent with agency theory so the financing decision is done by the manager to increase the asymmetric information and the agency costs as a monitoring effect. Both impact the decreasing of the firm's performance.

Trade-off Theory of Capital Structure. Leverage has advantages such as tax saving but also has disadvantages such as bankruptcy cost so the manager needs to balance the advantages and disadvantages of leverage in order to achieve an increase in performance. That statement is discussed in the trade-off theory of capital structure (Modigliani and Miller, 1963) which then developed by (Myers, 1984) who suggested that the company needs to arrange an optimal capital structure in order to optimize the firm's performance. But, the increase of leverage may decrease this performance because of the bankruptcy cost which is firm's inability to pay interest expenses that may cause the firm to default and face liquidation to pay those debts. As it is shown in Figure 1, managers can benefit from the advantage to use leverage until a certain level while anticipating the potentially increasing bankruptcy cost that may occur when the leverage usage has exceeded a certain level.

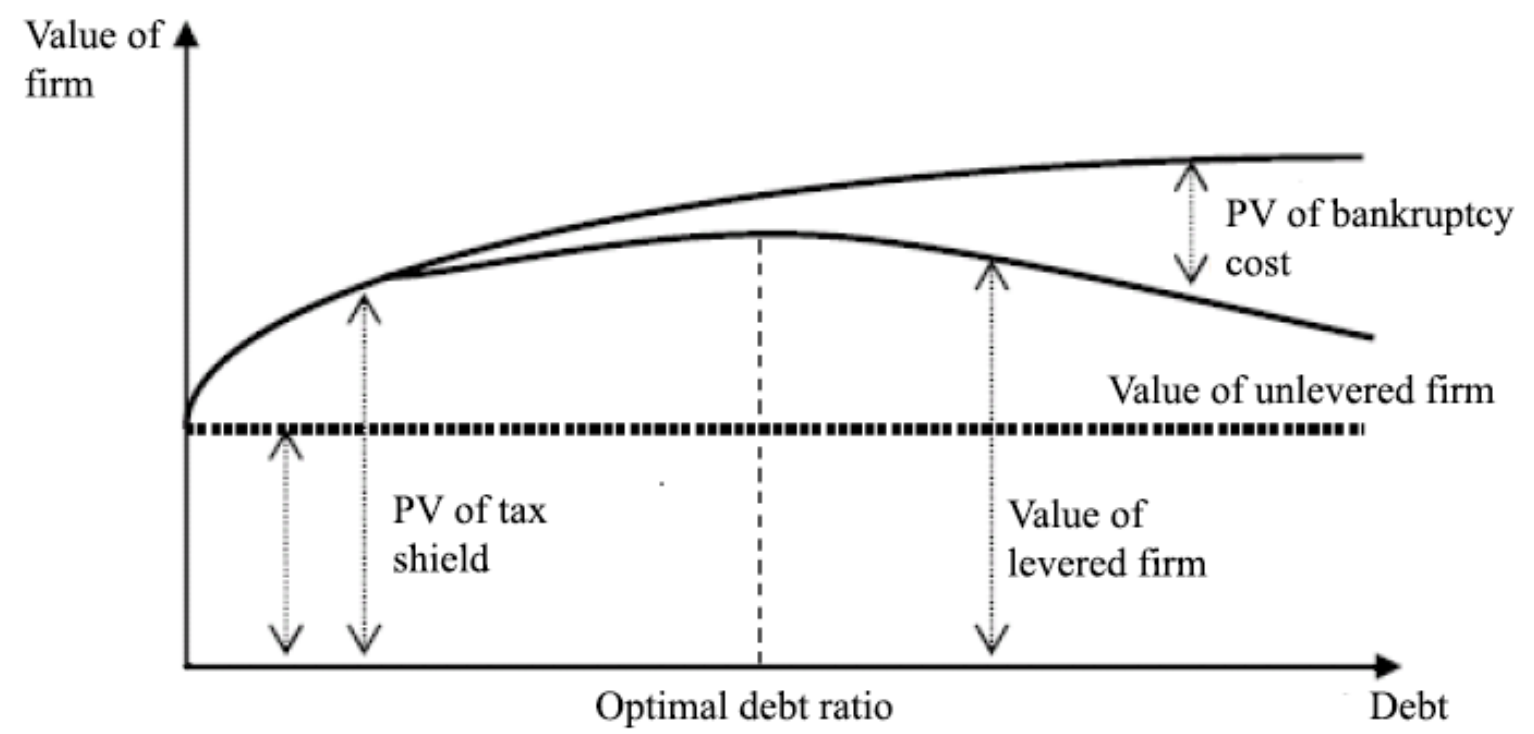

Figure 1. Static Trade-off Theory of Capital Structure Source: (Ghazouani, 2013)

Fig. 1 shows that an increase in leverage will increase the firm's performance because of the increase of tax saving, but the increase of leverage once it exceeds the optimal debt 
ratio will decrease the firm's performance which is caused by the increase of bankruptcy cost. That condition implies that a high-leveraged firm may result in high performance at first, but once the amount of leverage gets too high, the firm may face a decrease in the firm's performance due to bankruptcy cost that is higher than the tax saving.

Signaling Theory. Asymmetric information that occurs between manager and owner causes difficulty for the owner to make decisions or even to control the manager's decision. According to (Spence, 1973), the manager may give signals to the owner to give more information about the firm. Dividends distribution, for instance, is one of the most common signals that is done by the manager. Further, (Nurdin and Kasim, 2017) suggested that a high amount of dividend is a signal that the firm has a good performance which implies that an increase of dividend distribution will increase the firm's performance.

Managerial Ownership and Firm's Performance. The owner of the firm can increase managerial ownership to converge the interests of the owner and manager. (Vieira et al., 2019) suggested that the convergence of interests may motivate managers to increase the firm's performance because the increase of the firm's performance will increase the prosperity of the manager who has become the owner of the firm. In line with agency theory, the convergence of interests can decrease agency costs and increase the firm's performance (Ali et al., 2018) and the formulation of the hypothesis (H1a): Managerial ownership has a positive impact on firm's performance.

Parabolic Effect of Managerial Ownership on Firm's Performance. The prior study of (Morck et al., 1988) suggested that managerial ownership has a parabolic impact on firm's performance which is based on two hypotheses: (1) convergence of interest hypothesis, which is an increase of managerial ownership will reduce agency costs because there is a unification of manager's and owner's interests, and (2) entrenchment hypothesis, which is an increase of managerial ownership that is too high causes managers to act like owners so that the manager's role becomes dominant. This condition increases agency costs and thereby decreases performance.

Moreover, the study of (Ekadjaja et al., 2019) found the parabolic impact of managerial ownership on firm's performance in the form of u-shaped relationship which implies that an increase of managerial ownership until a certain level will reduce firm's performance and a further increase of managerial ownership after exceeding the certain level will increase firm's performance. While (Ping and Hsien, 2008) found the parabolic impact of managerial ownership on firm's performance to be in the form of inverse u-shaped relationship which implies that an increase of managerial ownership until a certain level will increase firm's performance and a further increase of managerial ownership after exceeding the certain level will decrease firm's performance. Referring to these results and in line with agency theory, the hypothesis formulation (H1b): Managerial ownership has a parabolic impact on a firm's performance.

Institutional Ownership and Firm's Performance. It is discussed in agency theory that institutional ownership conducts monitoring on managerial decisions which then limits the opportunistic behavior of managers, reduces agency costs, and increases the firm's performance (Kansil and Singh, 2018). Besides that, institutional ownership often does a 
strategic short-term investment which returns will increase the firm's performance (Misra and Kapil, 2017). In line with agency theory, the hypothesis formulation (H2): Institutional ownership has a positive impact on a firm's performance.

Family Ownership and Firm's Performance. The study of (Kao et al., 2019) shows that family ownership has a positive and significant impact on performance because family members have more detailed information about the firm compared to other ownerships. More detailed information means a decrease in asymmetric information which reduces agency costs and increases the firm's performance. In addition, family ownership can increase the efficiency of the firm's activities (Saleh et al., 2016) and increase the quality of earnings (Andayani et al., 2018). In line with agency theory, the hypothesis formulation (H3): Family ownership has a positive impact on a firm's performance.

Asset Growth and Firm's Performance. Managerial decision to increase assets is based on the expectations that the decision will result in incremental profit for the firm. Thus, the higher the asset growth, the higher the firm's performance will be (Inyiama et al., 2017). The manager invests in assets with the expectation that the assets will support the firm's activities and thereby will improve the firm's performance (Andayani et al., 2018). Based on the expectations that an increase in assets will result in a higher firm's performance, the hypothesis formulation (H4): Asset growth has a positive impact on a firm's performance.

Leverage and Firm's Performance. Manager can improve a firm's performance by balancing the benefits and cost of leverage as discussed in the trade-off theory of capital structure so that the higher the level of debt, the higher the firm's performance because the firm gets an increase of tax savings from interest payments. In addition, (Iqbal and Usman, 2018) suggest that an increase in leverage will increase the firm's financial capacity and will support performance improvement. In line with the trade-off theory of capital structure, the formulation of the hypothesis (H5): Leverage has a positive impact on a firm's performance.

Dividend Policy and Firm's Performance. The manager often gives a signal about the condition of the firm to the firm's owner as discussed in signaling theory. The signal is in the form of dividend distribution which is when manager distributes dividends, the manager implies that the firm has a good performance (Nurdin and Kasim, 2017) and when the manager increases the amount of dividend then the increase is sourced from increasing profit of the firm so it shows an increase of firm's performance (Khan et al., 2019). In line with signaling theory, the formulation of Hypothesis (H6): Dividend policy has a positive impact on a firm's performance.

Business Risk and Firm's Performance. Uncertainty in the business environment and competition causes volatility on firm revenue and increases the firm's risk. The risk is in the form of an inability to meet operational costs which cause the business risk and in turn, will cause a decrease in the firm's performance. However, (Alshubiri, 2015) found that business risk has a positive impact on performance because when a firm faces volatility then the firm will attempt to solve the volatility through innovation. Those innovations will then become a new resource for the firm and in turn, will increase revenue and business opportunity 
which will result in an increase in performance. Consistent with agency theory, the formulation of a hypothesis (H7): Business risk has a positive impact on a firm's performance.

Firm's Size and Firm's Performance. In general, big scaled firms will have good performance so an increase in the firm's size will increase the firm's performance (Khan et al., 2019). (Ho and Mohd, 2019) stated that when a firm is developing, the firm will earn some developments on market power, the economics of scale, and market experience which will in time increase the firm's performance. Furthermore, an increase of a firm's size plays a role in developing a firm's operational activities which will increase revenue and will finally increase the firm's performance (Ko et al., 2017). In accordance with what a firm will gain as it grows as stated above, the formulation of the hypothesis (H8): Firm's size has a positive impact on the firm's performance.

\section{METHODOLOGY}

The subject of this research is a non-financial firm that is listed on the Indonesian Stock Exchange in 2012-2018. The total number of population is 373 firms and this research uses purposive sampling with criteria such as a non-financial firm that has managerial ownership, institutional ownership, and family ownership at least in one year in the 20122018 period. The sample used in this research is 77 firms (539 firm-year). Eight independent variables used to predict a firm's performance are managerial ownership, institutional ownership, family ownership, leverage, asset growth, dividend policy, business risk, and firm's size. Besides that, this study also examines the parabolic impact of managerial ownership on a firm's performance

This research uses secondary data from the firm's financial report and financial report that was was published by Indonesia Capital Market Directory (ICMD) in 2012-2018. Multiple regression analysis is used to analyze the hypothesis by using Eviews 9.0 with the equation as follows:

$$
\begin{aligned}
& \mathrm{Q}_{\text {it }}=\alpha+\beta_{1} \mathrm{MOWN}_{\mathrm{it}}+\beta_{2} \mathrm{INST}_{\text {it }}+\beta_{3} \mathrm{FOWN}_{\mathrm{it}}+\beta_{4} \mathrm{LEV}_{\mathrm{it}}+\beta_{5} \mathrm{AG}_{\mathrm{it}}+\beta_{6} \mathrm{DPR}_{\mathrm{it}}+\beta_{7} \mathrm{EG}_{\mathrm{it}}+\beta_{8} \mathrm{SIZE}_{\mathrm{it}}+\varepsilon_{\mathrm{it}} \\
& \mathrm{Q}_{\mathrm{it}}=\alpha+\beta_{1} \mathrm{MOWN}_{\mathrm{it}}+\beta_{2} \mathrm{MOWN} 2_{\mathrm{it}}+\varepsilon .
\end{aligned}
$$

Notes:
Q $\quad=$ The firm's performance, that is measured by Tobin's Q which is the ratio of the market value of common stock and book value of total liabilities to total assets.
MOWN $=$ Managerial ownership is measured by the proportion of shares owned by the board of directors and the board of commissioners
MOWN2 = Quadratic value of managerial ownership (MOWN).
INST = Institutional ownership is measured by the proportion of shares owned by an institution.
FOWN $=$ Family ownership is measured by the proportion of shares owned by family members and entities of family members.
LEV $=$ Leverage is measured by the ratio of total debt to total assets.
$\mathrm{AG} \quad=$ Asset growth is measured by the ratio of increase or (decrease) of total assets to total assets of the prior year. 


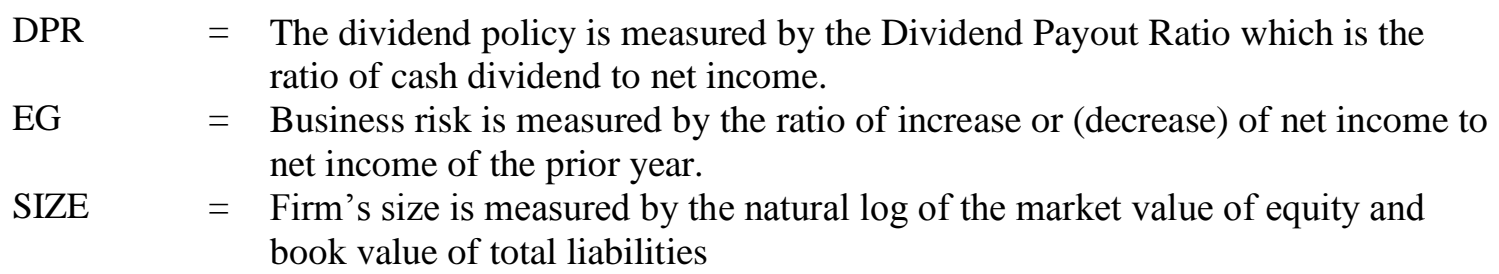

Equation 1 is used to examine the determinants of a firm's performance, while equation 2 is used to examine the parabolic effect of managerial ownership on a firm's performance. Furthermore, Chow and Hausman's test is done to determine the best-fitted regression model for examining the equations and it is found that Panel Least Square will be used to examine Equation 1, while Panel EGLS (cross-section random effects) will be used to examine Equation 2.

\section{THE RESULTS OF STATISTICAL TESTS}

This section describes the subject, object, and the result of statistical tests such as Descriptive Statistics, Multicollinearity test, Coefficient of Determination test, and t-Test. The subject of this research is a non-financial company that is listed in Indonesian Stock Exchange in 2012-2018 with a total amount of 373 companies which consist of 12 agriculture companies, 55 basic industry and chemicals companies, 38 consumer goods industry, 40 infrastructure, utilities, and transportation companies, 42 mining companies, 36 miscellaneous companies, 50 property, real estate, and building construction companies, and 100 trade, service, and investment companies.

Purposive sampling is then used as the sampling technique and 77 companies are used as the sample which consists of two agriculture companies, eight basic industry and chemicals companies, 12 consumer goods industry, 8 infrastructure, utilities, and transportation companies, 7 mining companies, four miscellaneous companies, 12 property, real estate, and building construction companies, and 24 trade, service, and investment companies. The description of the object is explained as follows:

Table 1. Descriptive Statistics

\begin{tabular}{lcccc}
\hline Variable & Rata-rata & Deviasi Standar & Minimum & Maksimum \\
\hline Tobin's Q & 1.348581 & 1.126517 & 0.163433 & 11.08736 \\
\hline MOWN & 0.064174 & 0.131691 & 0.000000 & 0.732031 \\
\hline INST & 0.643968 & 0.183903 & 0.016300 & 0.959600 \\
\hline FOWN & 0.474964 & 0.260018 & 0.000000 & 0.904200 \\
\hline LEV & 0.517170 & 0.201609 & 0.062563 & 1.291966 \\
\hline AG & 0.115639 & 0.205777 & -0.854541 & 1.695705 \\
\hline DPR & 0.157712 & 0.199509 & 0.000000 & 0.842862 \\
\hline EG & 0.158592 & 8.110519 & -71.48823 & 97.37532 \\
\hline SIZE & 12.48956 & 0.815367 & 10.49500 & 14.26907 \\
\hline
\end{tabular}

The firm's performance (Tobin's Q) has an average of 1.3485 which implies that nonfinancial firms in Indonesia have a high potential growth of investment and the manager 
manages assets efficiently as Tobin's Q value is higher than 1 (Sudiyatno and Puspitasari, 2010). However, a standard deviation of 1.126517 implies that there is a high deviation between the lowest value (0.163433) and the highest value of managerial ownership. This condition implies that the potential growth of investment tends to be low because the manager manages assets less efficiently and resulting in low Tobin's $Q$ value.

The average of managerial ownership is 0.064174 which implies that managerial ownership is low especially when being compared with the average of institutional and family ownership. This condition implies that there are firms that have not applied for managerial ownership in 2012-2018 which is shown by the minimum value of managerial ownership is 0 , as well as family ownership and dividend policy.

The ownership structure of non-financial firms in Indonesia is dominated by institutional ownership which is shown by the average of institutional ownership being $0.643968(64.3968 \%)$. This condition illustrates the condition of non-financial companies in Indonesia which is institutional ownership acts as the majority of stakeholders due to stock ownership being higher than 50\%. Besides that, among 373 observations, it is identified that only $2.68 \%$ or 10 firms have not applied for institutional ownership so the condition is different from the condition of managerial ownership.

The average family ownership is 0.474964 with a standard deviation of 0.260018 . This condition implies that family ownership is relatively high although lower than institutional ownership. Family ownership can be in the form of the founder's family members individually or institutions owned by the founder's family members, while nonfounders family members are not included as explained by (Azwari, 2016).

The average leverage is $0.517170(51.7170 \%)$ which implies that the proportion of debt funding is higher than stock funding which then becomes consistent with pecking order theory that states firm tends to firstly use leverage rather than stock funding. The average asset growth is 0.115639 with the minimum value of negative 0.854541 . The positive value of average reflects the asset growth that is done by non-financial firms in Indonesia which are increasing assets annually when it is possible to do so (the firm that earns profit will increase its assets, while a firm that does not earn profit will decrease its assets).

Dividend policy has an average of 0.157712 with the standard deviation of 0.199509 which implies that firms distribute dividends from $0.157712 \pm 19.95 \%$ of profit earned. But there is a high deviation in dividend payment which is caused by $48.24 \%$ (286 observations) do not distribute dividends, while 260 observations distribute dividends with the amount of less than $2.5 \%$ of profit earned with the highest value of 0.842862 . The variation in dividend distribution increases the deviation which then resulting in a high standard deviation.

The average business risk is 0.158592 with the standard deviation of 8.110519. A high standard deviation implies that there is high volatility in profit. This condition is in line with the growth of earnings after tax that occurred on non-financial companies in Indonesia which is a firm can earn profit in this year and faces loss in the next year and earn profit again in the following year, but the high variation may cause the business risk to not to have a significant impact on firm's performance.

The average firm's size is 12.48956 with a standard deviation of 0.815367 which implies that the capitalization of the market is relatively high. The standard deviation value is caused by the variation in market value with the lowest value being 10.49500 and the highest value being 14.26907. 
With the object has been described, a multicollinearity test is done to ensure that there is no multicollinearity in the regression model, especially between the independent variables. In accordance with (Ajija et al., 2011), the tolerance value of correlation is 0.8 , which means that two independent variables with correlation lower than 0.8 imply that there is no multicollinearity between the variables. The result is shown in Table 2 .

Table 2. Result of Multicolinearity Test

\begin{tabular}{lrrrrrrrr}
\hline & MOWN & INST & FOWN & LEV & AG & DPR & EG & SIZE \\
\hline MOWN & 1.00000 & & & & & & & \\
\hline INST & -0.57111 & 1.00000 & & & & & & \\
\hline FOWN & -0.01967 & 0.35104 & 1.00000 & & & & & \\
\hline LEV & -0.08066 & 0.14822 & -0.09519 & 1.00000 & & & & \\
\hline AG & 0.08385 & -0.09436 & -0.06262 & -0.01803 & 1.00000 & & & \\
\hline DPR & -0.10916 & -0.03290 & 0.18695 & -0.26287 & 0.08797 & 1.00000 & & \\
\hline EG & 0.00312 & -0.04586 & -0.00321 & -0.09285 & 0.01479 & 0.00923 & 1.00000 & \\
\hline SIZE & -0.00526 & -0.15445 & -0.09006 & 0.13589 & 0.10957 & 0.37843 & -0.05370 & 1.00000 \\
\hline
\end{tabular}

Table 2 shows that there is no correlation that is higher than 0.8 between the independent variables. The highest correlation value occurs between managerial ownership and institutional ownership which is -0.57111 so an increase of managerial ownership will decrease institutional ownership or vice versa. Besides that, institutional ownership can be in the form of family ownership (an institution owned by the founder's family members) which causes the institutional to have a positive correlation with family ownership.

The result of the multicollinearity test implies that there is no multicollinearity between independent variables and thus they can be used for the regression model. This study conducted the Chow Test and Hausman Test to determine the regression model that is best fitted for examining the equations. Based on the tests, Panel Least Square is used for Equation 1, and Panel EGLS (cross-section random effects) is used for Equation 2. The results are shown in Table 3 and Table 4.

Table 3. Regression Analysis Result of Equation 1

\begin{tabular}{lcccc}
\hline Variable & Coefficient & Prob. & Hypotheses & Result \\
\hline C & -23.26820 & 0.0000 & & \\
\hline MOWN & 1.149689 & 0.0040 & H1a & Accepted \\
\hline INST & 1.053148 & 0.0006 & H2 & Accepted \\
\hline FOWN & -0.675169 & 0.0046 & H3 & Rejected \\
\hline LEV & -0.654365 & 0.0042 & H4 & Rejected \\
\hline AG & -0.290875 & 0.0025 & H5 & Rejected \\
\hline DPR & 0.563377 & 0.0006 & H6 & Accepted \\
\hline EG & -0.001193 & 0.6147 & H7 & Rejected \\
\hline SIZE & 1.959146 & 0.0000 & H8 & Accepted \\
\hline $\mathrm{R}^{2}$ & 0.888420 & Adj. $\mathrm{R}^{2}$ & 0.867775 & \\
\hline
\end{tabular}

Table 3 illustrates that managerial ownership, institutional ownership, dividend policy, and firm size have a positive and significant impact on a firm's performance, while family ownership, asset growth, and leverage have a negative impact on a firm's 
performance. However, the business risk has a negative impact and an insignificant impact on a firm's performance. Adjusted $\mathrm{R}^{2}$ is valued at $86.78 \%$ which implies that the independent variables can describe a firm's performance by $86.78 \%$, while the remaining $13.22 \%$ can be described by other variables, such as macroeconomics factors.

Table 4. Regression Analysis Result of Equation 2

\begin{tabular}{lcccc}
\hline \multicolumn{1}{c}{ Variable } & Coefficient & Prob. & Hypotheses & Result \\
\hline $\mathrm{C}$ & 1.178722 & 0.0000 & & \\
\hline MOWN & 4.642687 & 0.0000 & H1b & Accepted \\
\cline { 1 - 3 } MOWN2 & -5.977007 & 0.0002 & & \\
\hline $\mathrm{R}^{2}$ & 0.056522 & Adj. $\mathrm{R}^{2}$ & 0.053002 & \\
\hline
\end{tabular}

Lastly, Table 4 depicts that managerial ownership has a parabolic and significant impact on a firm's performance. It is shown there that the quadratic value of managerial ownership (MOWN2) has a negative coefficient which implies that the curve of parabolic impact is in the form of an inverse $\mathrm{u}$-shaped relationship.

\section{DISCUSSION}

The positive impact of managerial ownership implies that the mechanism of managerial ownership converges the interests of the manager and owner. The result is consistent with the study of (Alabdullah, 2017; Berke et al., 2017; Jiang and Zhang, 2017; Ali et al., 2018; Vieira et al., 2019). The convergence of interests motivates managers to perform better with the expectation to increase the firm's performance as an increase of the firm's performance will also increase the prosperity of the manager who has become the owner of the firm (Ali et al., 2018; Vieira et al., 2019). The result is consistent with the convergence of interest hypothesis as stated by (Morck, 1988) that managerial ownership decreases agency costs due to the convergence of interests.

Despite managerial ownership having a positive impact on a firm's performance, managerial involvement in stock ownership is still low with an average of $6.4174 \%$ so it needs to be increased for the purpose to increase the firm's performance. But, institutional ownership will decrease as managerial ownership increases because the two independents correlate negatively, therefore the mechanism to increase managerial ownership needs to balance with institutional ownership because institutional ownership has a positive and significant impact on the firm's performance as well. According to (Ping and Hsien, 2008) stated that institutional ownership generally is in the form of a parent entity or subsidiary. Therefore, this statement reflects the firms' condition in Indonesia so a decrease of institutional ownership can be done in order to increase managerial ownership.

Nevertheless, the entrenchment hypothesis as stated by (Morck, 1988) emphasizes that managerial ownership has a parabolic impact on a firm's performance. The result finds the parabolic impact is in the form of an inverse u-shaped relationship which means that an increase of managerial ownership until a certain level will increase the firm's performance, but after exceeding a certain level, the increase of managerial ownership will decrease firm's performance instead. The non-linear pattern of the relationship between managerial ownership and firm performance is shown in Fig. 2. The result gives different evidence with the previous study by (Ekadjaja et al., 2019) although it uses the same subject which is non- 
financial firms that are listed in the Indonesian Stock Exchange a different period of time was used in the study.

Moreover, (Ekadjaja et al., 2019) conducted the study on non-financial firms that is listed in Indonesian Stock Exchange in the period of 2000-2017 with the optimal point of the non-linear pattern being $42.77 \%$ and a u-shaped relationship between managerial ownership and firm's performance, while this study uses the period of 2012-2018 with the optimal point of the non-linear pattern being $38.84 \%$. The result indicates that there can be another relatively strong factors impacting firm's performance such as institutional ownership and family ownership which were not examined in the study of (Ekadjaja et al., 2019), as well as fundamental factors such as leverage, asset growth, dividend policy, and firm's size. The result is proved by the adjusted $\mathrm{R}^{2}$ of $86.78 \%$. Basically, the optimization of managerial ownership management can be used as a mechanism to reduce agency conflict and increase the firm's performance.

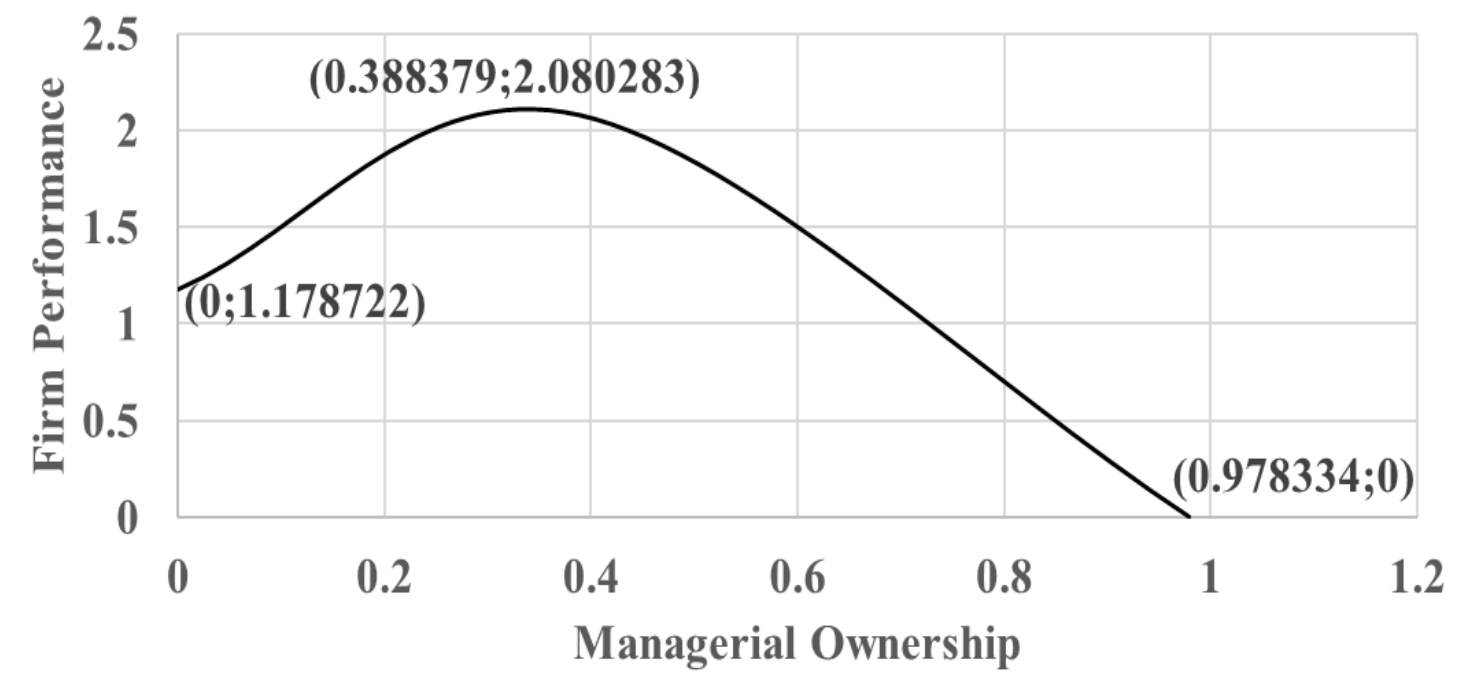

Figure 2. The Parabolic Impact of Managerial Ownership on Firm's Performance

Fig. 2 depicts that the increase of managerial ownership until it reaches $38.84 \%$ will result in the increase of the firm's performance but the increase of managerial ownership after it exceeds $38.84 \%$ will decrease the firm's performance instead. Therefore, the convergence of interest hypothesis occurs when managerial ownership is lower than $38.84 \%$ and the entrenchment hypothesis occurs when managerial ownership is higher than $38.84 \%$.

The positive impact of institutional ownership on a firm's performance is caused by its capacity to control the manager's behavior which is better than the other kind of ownership structure. The result is consistent with the study of (Masry, 2016; Hamdan, 2017; Mishra and Kapil, 2017; Kao et al., 2019). Therefore, the mechanism of institutional ownership can decrease agency costs and will finally increase the firm's performance. Besides, institutional ownership conducts a short period of strategic investment that generates profit from various investments (Mishra and Kapil, 2017). This condition becomes a controlling mechanism to manage the agency conflict of managers. 
Family ownership has a negative impact on a firm's performance which can be caused by its behavior to not involve any manager who is not a family member and doing so will limit innovation, capability, and creativity of the firm (Shen et al, 2017; Maqsad, 2018). The behavior is in line with the condition of non-financial firms in Indonesia which is shown from there are managers who also act as managers in other firms which is the parent entity or subsidiary of the firm.

In accordance with the trade-off theory of capital structure, the negative impact of leverage on a firm's performance is caused by the interest expense of the leverage and bankruptcy cost (Kao et al., 2019). The result is consistent with the study of (Evgeny, 2015; Hastuti, 2018; Vieira et al., 2019). In accordance with agency theory and pecking order theory, financing decision increases asymmetric information which in time will increase agency costs. Therefore, this condition is confirmed as a factor that decreases performance. The average leverage is $51.72 \%$ which is relatively high and it shows that the firm's assets are mostly financed with debts and not internal financing or stock issuance. This condition is then consistent with the trade-off theory of capital structure which is when a firm uses a high level of leverage financing, it will decrease performance because of its bankruptcy cost and debt agency cost.

The negative impact of asset growth is caused by the increase of assets that cannot support firm's activities and therefore can't increase revenue and becomes an incremental cost instead. The cost can be in the form of holding cost, asset maintenance, and interest expense cost which occurs when the increased assets are financed by debts, which this research shows to have a negative and significant impact on performance. The result is consistent with the study of (Maggina and Tsaklanganos, 2012).

The positive impact of dividend policy on the firm's performance is caused by a firm that distributes dividend is considered to have a good performance which is relevant with signaling theory (Nurdin and Kasim, 2017). The result is consistent with the study of (Nurdin and Kasim, 2017; Hafeez et al, 2018; Khan et al., 2019). When there is an increase in dividends, the dividend is distributed from the increase of the firm's profit which is a form of an increase in the firm's performance (Khan et al., 2019). In general, non-financial firms in Indonesia which earn profit will distribute dividend. From 424 observations in which the firm earns profit, $67.45 \%$ does dividend distribution which can be considered as a signal to stakeholders that the firm has a good performance.

Business risk has a negative impact on a firm's performance which is caused by the volatility of revenue and is even worse when the volatility is showing a downfall trend (Ko et al., 2017). The negative impact of business risk on the firm's performance is consistent with the study of (Kahloul and Hallara, 2010; Saleh et al., 2016; Ko et al., 2017). Despite of the business risk does not significantly impact performance, as found by (Vakilifard and Oskouei, 2014). The insignificant result can be caused by the operationalization of the business risk variable which is using earnings growth that may not really represent the volatility of the firm's profit since the standard deviation is very high. The volatility calculated by the proxy is the growth of the firm's net profit every two years which may not explain business risk accurately.

The positive impact of a firm's size on a firm's performance is caused by the development of market power, the economics of scale, and market experience along with the increase of the firm's size (Ho and Mohd, 2019). Besides that, an increase in a firm's size plays a role in developing a firm's operational activities (Ko et al., 2017) which in turn 
will increase the firm's performance. The result is consistent with the study of (Shyu, 2011; Ko et al., 2017; Ho and Mohd, 2019; Khan et al., 2019; Oyelade, 2019).

\section{CONCLUSION}

This study finds that managerial ownership, institutional ownership, dividend policy, and firm size have a positive and significant impact on a firm's performance, while family ownership, leverage, and asset growth have a negative and significant impact on a firm's performance. Even though there is one variable that does not impact a firm's performance significantly, but the entire ownership structure can be used as the controlling mechanism for agency conflict. Therefore, future studies can use the operationalization variable of business risk in the form of standard deviation that calculates the volatility of a firm in a longer time period on the earnings-to-price ratio (Alshubiri, 2015) or monthly stock closing price for 1 year (Nuringsih, 2010).

The findings also show that a firm can increase its managerial ownership by $38.84 \%$ to increase the firm's performance. An increase of managerial ownership needs to be followed by a decrease of institutional ownership because both factors correlate negatively, but this research suggests to increase managerial ownership because it has a higher regression coefficient compared with institutional ownership which means that an increase of managerial ownership will increase more performance than an increase of institutional ownership does. With this pattern, it is found that an increase of managerial ownership until a certain point can be used as a mechanism to control agency conflict

A negative impact is found from leverage to firm's performance which is caused by the use of leverage that is too high so future research needs to study the potential parabolic impact of leverage on firm's performance to discover if the negative impact of leverage is actually caused by leverage usage that is too high as stated in trade-off theory of capital structure.

It is expected that the result of this study can be used by society as a reference about factors enhancing a firm's performance and factors decreasing performance so then it can be used to help them in terms of investment decision making. This result can also be used for students and researchers to build knowledge and as a literature review to conduct research on firm's performance.

Future research on the firm's performance needs to be done especially due to some limitations in this study which are this study does not analyze financial firms in Indonesia and does not analyze the impact of macroeconomics factors on a firm's performance. The study of macroeconomics factors as a determinant of a firm's performance needs to be conducted to study how a nation's macroeconomics factors may impact the performance of firms that operate within it.

\section{REFERENCES}

Adair, P., and Adaskou, M. (2015). "Trade-Off Theory vs. Pecking Order Theory and the Determinants of Corporate Leverage: Evidence from a Panel Data Analysis upon French SMEs (2002-2010)". Cogent Economics \& Finance 3(1): 1-12. DOI: 10.1080/23322039.2015.1006 477. 
Ahmed, F., Awais, I., and Kashif, M. (2018). "Financial Leverage and Firms' Performance: Empirical Evidence from KSE-100 Index". Etikonomi 17(1): 45-56. DOI: 10.15408/etk.v17i1.6102.

Ajija, S. R., Sari, D. W., Setianto, R. H., and Primanta, M. R. (2011). Cara Cerdas Menguasai Eviews. Edisi ke Empat, Jakarta: Salemba Empat.

Alabdullah, T. T. Y. (2017). "The Relationship between Ownership Structure and Firm Financial Performance”. Benchmarking: An International Journal 25(1): 319-333. DOI: 10.1108/BIJ-04-2016-0051.

Allam, B. S. (2018). "The Impact of Board Characteristics and Ownership Identity on Agency Costs and Firm Performance: UK Evidence". Corporate Governance 18(6): 1.147-1.176. DOI: 10.1108/CG-09-2016-0184.

Ali, A., Qiang, F., and Ashraf, S. (2018). "Regional Dynamics of Ownership Structure and Their Impact on Firm Performance and Firm Valuation". Review of International Business and Strategy 28(1): 128-146. DOI: 10.1108/RIBS-02-2017-0017.

Alshubiri, F. (2015). "Measurement the Impact of Financial and Business Risk on Performance: Evidence of Industrial Sector of Oman". Asian Social Science 11(22): 26-32. DOI: 10.5539/ass.v11n22p26.

Andayani, W., Hartono, J., Supriyadi, and Miharjo, S. (2018). "The Effect of Family Ownership on Profit and Performance Company Management: Based on The Theory of Stewardship". Journal of Applied Management 16(2): 336-352. DOI: 10.21776/ub.jam.2018.016.02.17.

Azwari, P. C. (2016). "Masalah Keagenan pada Struktur Kepemilikan Perusahaan Keluarga di Indonesia". Jurnal Ilmu Akuntansi 9(2): 173-184. DOI: 10.15408/akt.v9i2.4021.

Berke-Berga, A., Doyladbekova, I., and Abula, M. (2017). Managerial Ownership and Firm Performance: Evidence of Listed Companies in the Baltics". Polish Journal of Management Studies 15(2): 273-283. DOI: 10.17512/pjms.2017.15.2.25.

BPS. (2020) Ekonomi Indonesia 2019 Tumbuh 5.02 Persen (Retrieved from: https://tapanulitengahkab.bps.go.id/pressrelease/2020/02/08/113/ekonomi-indonesia2019-tumbuh-5-02-persen/ February $8^{\text {th }}, 2020$ ).

Ekadjaja, M., Siswanto, H. P., Nuringsih, K., and Amelinda, R. (2019). "Parabolic Effect Between Managerial Ownership and Firm Value to Control Agency Conflict". Jurnal Manajemen 23(3): 355-374. DOI: 10.24912/jm.v23i3.569.

Evgeny, I. (2015). “The Impact of Financial Leverage on Firm Performance: Evidence from Russia. Journal of Corporate Finance Research 2(34): 24-36.

Ghazouani, T. (2013). "The Capital Structure through the Trade-Off Theory: Evidence from Tunisian Firm”. International Journal of Economics and Financial Issues 3(3): 625636.

Hafeez, M. M., Shahbaz, S., Iftikhar, I., and Butt, H. A. (2018). "Impact of Dividend Policy on Firm Performance: Evidence from the Manufacturing Firms in Pakistan". International Journal of Advance Study and Research Work 1(4): 1-5. DOI: 10.5281/zenodo.1312180.

Hamdan, A. (2017). "Board Interlocking and Firm Performance: The Role of Foreign Ownership in Saudi Arabia. International Journal of Managerial Finance 14(3): 266281. DOI: 10.1108/IJMF-09-2017-0192. 
Hastuti, R. T. (2018). "Faktor yang Mempengaruhi Firm Performance pada Perusahaan Manufaktur yang Terdaftar di BEI. Jurnal Muara Ilmu Ekonomi dan Bisnis 2(1): 181 187.

Ho, C. S. F., and Mohd-Raff, N. E. N. (2019). "External and Internal Determinants of Performances of Shariah and non-Shariah Compliant Firms". International Journal of Islamic and Middle Eastern Finance and Management 12(2): 236-253. DOI: 10.1108/IMEFM-08-2017-0202.

Inyiama, O. I., Ugbor, Oluchukwu, R., and Nnenna, C. V. (2017). "Evaluation of the Relationship between Assets Growth Rate and Financial Performance of Manufacturing Firms in Nigeria”. International Journal of Managerial Studies and Research (IJMSR) 5(10): 63-73. DOI: 10.20431/2349-0349.0510006.

Iqbal, U., and Usman, M. (2018). "Impact of Financial Leverage on Firm Performance". SEISENSE Journal of Management 1(2): 70-78. DOI: 10.5281/zenodo.1241454.

Jabbary, H., Hajiha, Z., and Labeshka, R. H. (2013). "Investigation of the Effect of Agency Costs on Firm Performance of Listed Firms in Tehran Stock Exchange". European Online Journal of Natural and Social Sciences 2(3): 771-776.

Jensen, M. C., and Meckling, W. H. (1976). "Theory of the Firm: Managerial Behavior, Agency Costs and Ownership Structure”. Journal of Financial Economics 3(4): 305360.

Jiang, H., and Zhang, H. (2017). "Regulatory Restriction on Executive Compensation, Corporate Governance and Firm Performance". Asian Review of Accounting 26(1): 131-152. DOI: 10.1108/ARA-07-2016-0080.

Kansil, R., and Singh, A. (2018). "Institutional Ownership and Firm Performance: Evidence from Indian Panel Data”. International Journal and Emerging Markets 10(3): 250269. DOI: 10.1504/IJBEM.2018.10013055.

Kahloul, I., and Hallara, S. (2010). "The Impact of Diversification on Firm Performance and Risk: An Empirical Evidence. International Research Journal of Finance and Economics 35: 150-162.

Kao, M. F., Hodgkinson, L., and Jaafar, A. (2019). "Ownership Structure, Board of Directors and Firm Performance: Evidence from Taiwan". Corporate Governance 19(1): 189-216. DOI: 10.1108/CG-04-2018-0144.

Ko, C., Lee, P., and Anandajaran, A. (2017). "The Impact of Operational Risk Incidents and Moderating Influence of Corporate Governance on Credit Risk and Firm Performance". International Journal of Accounting \& Information Management 27(1): 96-110. DOI: 10.1108/IJAIM-05-2017-0070.

Khan, K., Lamrani, H. C., and Khalid, S. (2019). "The Impact of Dividend Policy on Firm Performance: A Case Study of the Industrial Sector". Risk Governance \& Control: Financial Markets \& Institutions 9(3): 24-31. DOI: 10.22495/rgcv9i3p2.

Maggina, A., and Tsaklanganos, A. (2012). "Asset Growth and Firm Performance Evidence from Greece. The International Journal of Business and Finance Research 6(2): 113124.

Maqsad, M. A. (2018). "The Impact of Ownership Structure on Firm Performance: Evidence from Jordan". Academy of Accounting and Financial Studies Journal 22(5): 1-9. DOI: $1528-2635-22-5-289$. 
Masry, M. (2016). "The Impact of Institutional Ownership on the Performance of Companies Listed in the Egyptian Stock Market. IOSR Journal of Economics and Finance 7(1): 5-15. DOI: 10.9790/5933-07130515.

Mishra, R., and Kapil, S. (2017). "Effect of Ownership Structure and Board Structure on Firm Value: Evidence from India". Corporate Governance 17(4): 700-726. DOI: 10.1108/CG-03-2016-0059.

Modigliani, F., and Miller, M. H. (1963) "Corporate Income Taxes and the Cost of Capital: A Correction". The American Economic Review 53(3): 433-443.

Morck, R., Shleifer, A., and Vishny, R. W. (1988). "Management Ownership and Market Valuation". Journal of Financial Economics 20: 293-315.

Myers, S. C. (1984) "The Capital Structure Puzzle". The Journal of Finance 39(3): 575592.

Myers, S. C., and Majluf, N. S. (1984) "Corporate Financing and Investment Decisions When Firms Have Information that Investors Do Not Have". Journal of Financial Economics 13(2): 187-221.

Nurdin, D., and Kasim, M. Y. (2017). "Moderator Effect of Corporate Governance on the Relationship of Financial Performance and Dividend Policy, and Its Impact on Firm Value in Indonesia Stock Exchange". International Journal of Economics \& Management Sciences 7(1): 1-7. DOI: 10.4172/2161-6359.1000499.

Nuringsih, K. (2010). "Pengaruh Profitabilitas, Kebijakan Hutang dan Kepemilikan Institusional terhadap Kepemilikan Manajerial dan Pengaruhnya terhadap Risiko". Jurnal Bisnis dan Akuntansi 12(1): 17-28.

Oyelade, A. (2019). "The Impact of Firm Size on Firms Performance in Nigeria: A Comparative Study of Selected Firms in the Building Industry in Nigeria". Asian Development Policy Review 7(1); 1-11. DOI: 10.18488/journal.107.201971.1.11.

Panda, B., and Leepsa, N. M. (2017). "Agency Theory: Review of Theory and Evidence on Problems and Perspective”. Indian Journal of Corporate Governance 10(1): 74-95. DOI: $10.1177 / 0974686217701467$.

Ping, L. S. and Hsien, C. T. (2008). "The Determinants of Corporate Performance". Managerial Auditing Journal 24(3): 233-247. 10.1108/02686900910941122.

Saleh, A. S., Halili, E., Zeitun, R., and Salim, R. (2016). "Global Financial Crisis, Ownership Structure and Firm Financial Performance". Studies in Economics and Finance 34(4): 447-465. DOI: 10.1108/SEF-09-2016-0223.

Shan, Y. G. (2017). "Managerial Ownership, Board Independence and Firm Performance". Accounting Research Journal 32(2): 203-220. DOI: 10.1108/ARJ-09-2017-0149.

Shen, N. Au, K., and Yi, L. (2017). "Diversification Strategy, Ownership Structure, and Financial Crisis: Performance of Chinese Private Firms". Asia-Pacific Journal of Financial Studies 47: 54-80. DOI: 10.1111/ajfs.122203.

Shyu, J. (2011). "Family Ownership and Firm Performance: Evidence from Taiwanese Firms". International Journal of Managerial Finance 7(4): 397-411. DOI: 10.1108/174391311111166393.

Spence, M. (1973). “Job Market Signaling”. The Quarterly Journal of Economics 87(3): 355-374.

Sudiyatno, B., and Puspitasari, E. (2010). “Tobin's Q dan Altman Z-Score sebagai Indikator Pengukuran Kinerja Perusahaan”. Kajian Akuntansi: 9-21. 
Vakilifard, H. R., and Oskouei, M. M. (2014). "The Effect of Risk on Firm Performance: Evidence from Automobile Companies Listed in Tehran Stock Exchange (TSE)". Middle-East Journal of Scientific Research 19(6): 740-746. DOI: 10.5829/idosi.mejsr.2014.19.6.5353.

Vieira, E. S., Neves, M. E. and Dias, A. G. (2019). “Determinants of Portuguese Firm's Financial Performance: Panel Data Evidence". International Journal of Productivity and Performance Management 68(7): 1.323-1.342. DOI: 10.1108/IJPPM-06-20180210 . 